\title{
Odonata checklist of Nature Reserve and SAC (Special Area of Conservation) "Vallone di Piano della Corte" (Sicily, Italy)
}

\author{
Paolo Galasso' \& Renzo lentile $2^{*}$ \\ ${ }^{1}$ Stiftung Pro Artenvielfalt ${ }^{\circledR}$, Meisenstraße 65, 33607 Bielefeld, Germany; e-mail: paolo galasso@hotmail.com; \\ ${ }^{2}$ Centre for the Conservation and Management of Nature and Agroecosystems (CUTGANA), Via Santa Sofia, 98, 95123 Cata- \\ nia, Italy; e-mail: renzoientile@unict.it; \\ ${ }^{*}$ Corresponding author
}

\begin{abstract}
From March to September 2018 and 2019, a first monitoring of Odonata promoted by CUTGANA was conducted inside a site of Natura 2000 network, named "Vallone di Piano della Corte", near Agira (Enna), Sicily. A total of 21 different species were recorded, including Pyrrhosoma nymphula (Sulzer, 1776), for which there are no stations reported for this side of Sicily.
\end{abstract}

KEY WORDS Dragonflies; Erei; Natura 2000; Odonata; Pyrrhosoma nymphula.

Received 06.08.2020; accepted 29.08.2020; published online 06.11.2020

\section{INTRODUCTION}

Up to date, 165 species of Odonata are so far reported for the Mediterranean basin area (Boudot et al., 2009; Boudot \& Kalkman, 2015). Among them, 144 are reported for Europe and 96 for Italy, of which 58 species occurring in Sicily (Riservato et al., 2014; Galasso et al., 2016; Viganò et al., 2017; Surdo, 2017; Corso \& Penna, 2020). The number of species in Sicily is probably destined to grow further thanks to the intensification of the knowledges and research activities, until today mostly limited to main wetlands and water habitats.

This short note is a small contribute to the information on Sicilian dragonflies related to a never before studied area for what concerns this taxon.

\section{MATERIAL AND METHODS}

\section{Study area}

The study area, named "Vallone di Piano della
Corte", is a valley crossed by a stream located in the middle part of the Erei mounts, Sicily, in the municipality of Agira, province of Enna $\left(37^{\circ} 38^{\prime} 44.32\right.$ 'N $14^{\circ} 29^{\prime} 44.58^{\prime}$ 'E, Fig. 1). This survey was primarily focused along the main stream which flows through to the valley, named "Torrente Brace", its tributaries, and all the surrounding minor water habitats such as small lakes, troughs and natural ponds (Fig. 2). The stream, starting from its source is up to $6 \mathrm{~km}$ long and has an extended surface of 146 hectares. In addition, the stream is included in the regional nature reserve "Vallone di Piano della Corte".

The nature reserve was established from Regione Sicilia (Assessorato Regionale del Territorio e dell'Ambiente) in 2000, and is presently managed by CUTGANA (Centro Universitario per la Tutela e la Gestione degli Ambienti Naturali e degli Agro-ecosistemi) of Catania's University. Furthermore, since 2005, 450 hectares of the valley are included in the network of Natura 2000 as Special Area of Conservation (SAC ITA060007). The valley of Brace's stream is bordered by reliefs 
of 500-800 m a.s.1., including mount "Teja", where the town of Agira is located. The early stretch of the stream, located in "Santa Venera" disctrict, crosses sandy soils and is characterized by a luxuriant vegetation with forest of Salix alba and Populus alba, with some old trees of Populus nigra (Fig. 3). The remaining part of the stream, inside the so-called district "Ponte", is instead characterized by clay soils and trees of Tamarix sp. alternated to open meadows. The whole stream bed is usually dry for the most of the year, with the occasional exception of residual pools which are instead always present in the middle due to spring waters, even during the Summer. For additional botanic insights see Costanzo et al. (2005). In the study area, near to "Monte S. Agata", there are also some drinking troughs for cattle and two artificial water reservoirs, about 5 and $1,300 \mathrm{~m}^{2}$ wide, respectively.

Additional data about Odonata were also obtained in the nearby area of "Monte Chiapparo", included in another Special Area of Conservation Natura 2000 (ITA060014) as well in an artificial water reservoir $700 \mathrm{~m}^{2}$ wide. The site is located north of mount Chiapparo, in the Contrada San Nicola.

\section{Samples}

The method used has been the "capture-identification-release", walking through transects along the main stream of the valley and from points of

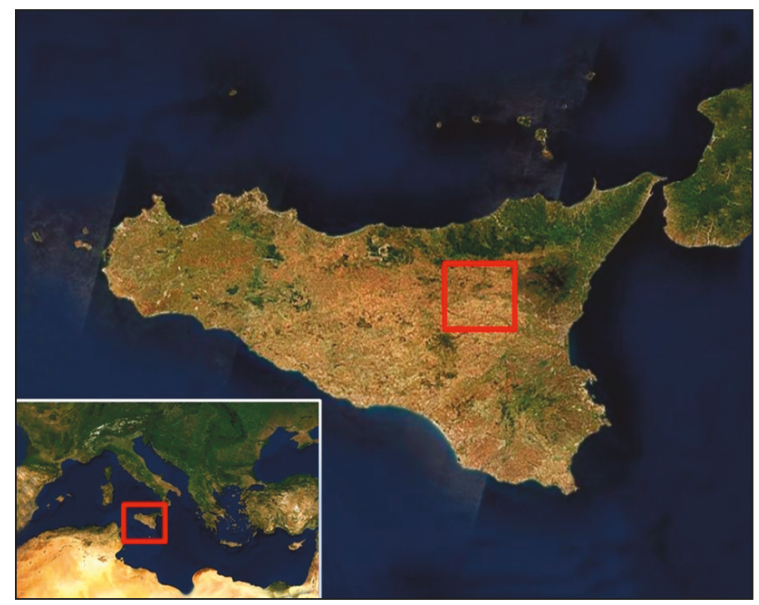

Figure 1. Geographical location of the study area, in the centre-north Sicily, west side of mount Etna. interest near to natural small lakes, ponds and drinking troughs. They were carried out once a week, from March 2018 to September 2018 and from March 2019 to September 2019. The sampling was done always during the morning and with good weather conditions (no rain and no wind), when the dragonflies activity is more intense and the identification was made mainly collecting and releasing the specimens with entomological nets, or, in other cases, through direct observation with binocular and collection of photographic material.

\section{RESULTS}

\section{Systematics}

Ordo ODONATA Fabricius, 1793

Subordo ZYGOPTERA de Sélys Longchamps, 1854

Familia CALOPTERYGIDAE Sélys, 1850

Genus Calopteryx Leach, 1815

Calopteryx haemorrhoidalis (Vander Linden, 1825)

This species has been regularly observed in 2018/19, from early May to September, even without a high numbers of imagoes, especially in the middle trait of the Brace stream, mostly shady and rich in vegetation. Breeding was confirmed in the study area.

Familia LESTIDAE Calvert, 1901

Genus Sympecma Burmeister, 1839

Sympecma fusca (Vander Linden, 1820)

Imagoes evenly observed in the whole area from April to September of both years, almost in all the habitats along the Brace stream and in the troughs. Breeding confirmed.

Genus Chalcolestes Kennedy, 1920 


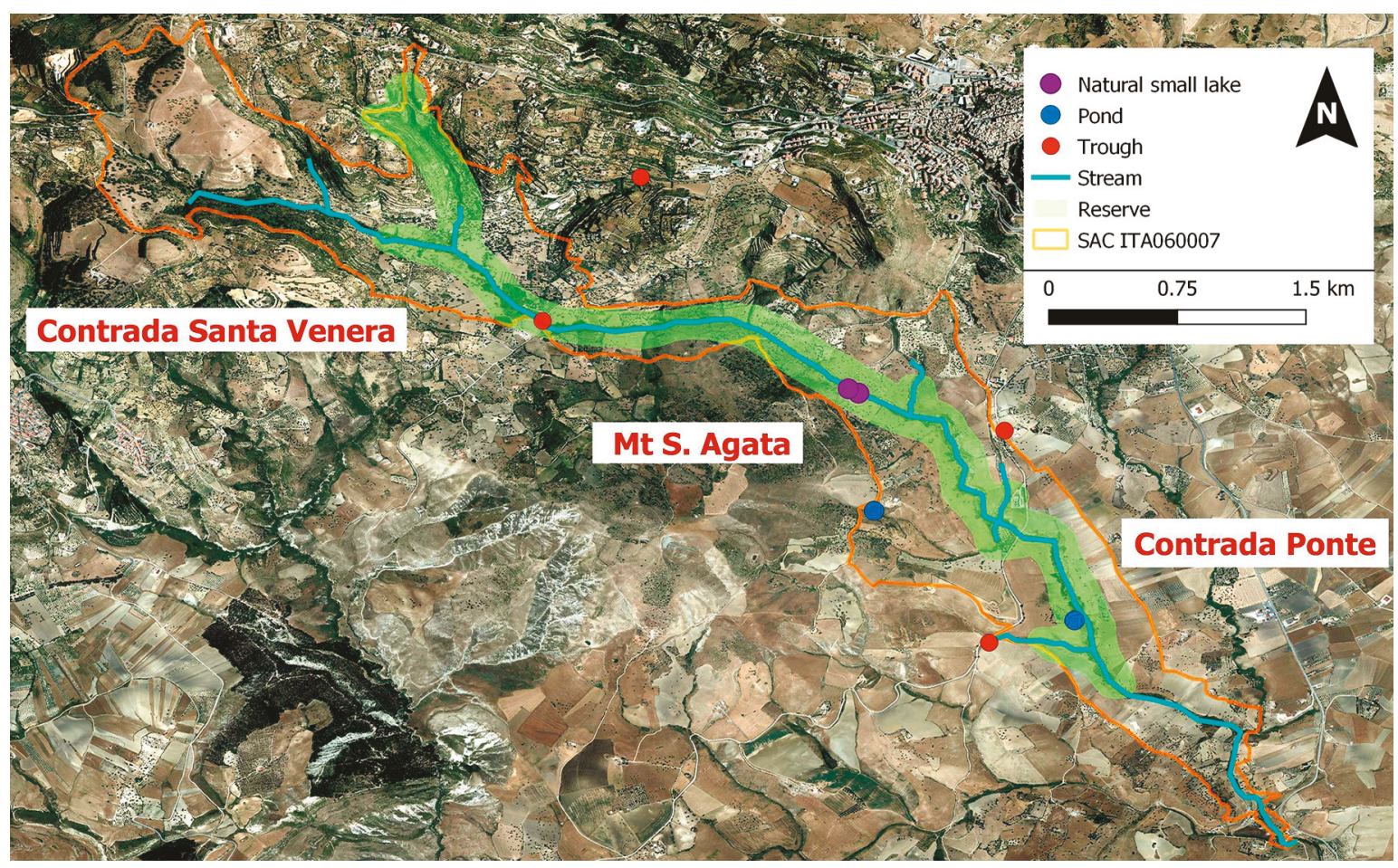

Figure 2. Map of Vallone di Piano della Corte, with the main points of interest for Odonata monitoring used for this survey and delimitation of protected areas.

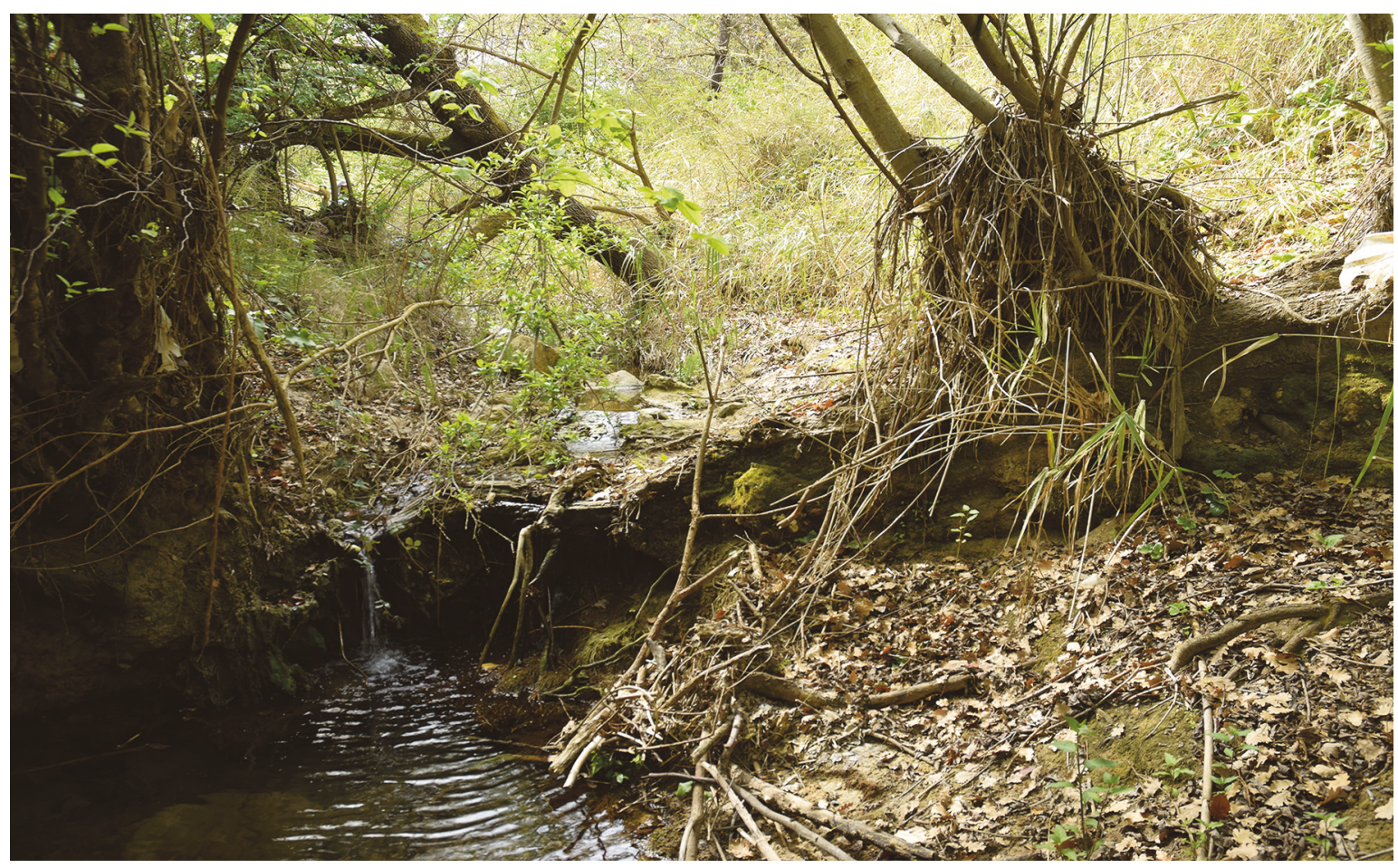

Figure 3. Representative habitat with Salix alba trees along side the Brace stream, "Vallone di Piano della Corte", near Agira (Enna), Sicily. 


\section{Chalcolestes viridis (Vander Linden, 1825)}

Males and females imagoes observed regularly from June to September of both years but only in some shady stretches of the upper and middle part of Brace stream. Found also at a great distance from water in a coniferous wood in September 2019. Breeding confirmed.

Familia COENAGRIONIDAE Kirby, 1890

Genus Ceriagrion Sèlys, 1876

\section{Ceriagrion tenellum (de Villers, 1789)}

Regularly observed from May to September of both years mainly in open habitats as ponds, troughs and in the small lake, but also in some opened and sunny stretches of Brace stream. Breeding was confirmed.

Genus Coenagrion Kirby, 1890

Coenagrion scitulum (Rambur, 1842)

Pretty common species, imagoes observed regularly from May to September 2018/19, mainly in open habitats as ponds and in the small lake, but also in some opened and sunny stretches of Brace stream. Breeding confirmed.

Genus Erythromma Charpentier, 1840

Erythromma viridulum (Charpentier, 1840)

Few imagoes, males and females, observed from June to late September, both in 2018 and 2019, exclusively in ponds and small lake. Breeding was confirmed for the study area. Also recorded in Monte Chiapparo.

Genus Ischnura Charpentier, 1840

Ischnura genei (Rambur, 1842)

The commonest damselflies in the area, regularly observed from March to September in all the habitats monitored. Breeding was confirmed. Also recorded in Monte Chiapparo.
Genus Pyrrhosoma Charpentier, 1840

Pyrrhosoma nymphula (Sulzer, 1776)

Few imagoes observed (4-5), also during mating and oviposition (Fig. 4), on 28.V.2018. This species was found only in one station, in the upper part of the study area, named Contrada Santa Venera.

Subordo ANISOPTERA de Sélys Longchamps, 1854 Familia AESHNIDAE Rambur, 1842

Genus Aeshna Fabricius, 1775

Aeshna isoceles (Müller, 1767)

Only 1 imago observed in flight on 28.V.2018, along the Brace stream near S. Agata mountain.

Aeshna mixta (Latreille, 1805)

Only 3 imagoes, 2 males and 1 female, observed in September 2018. These low records are probably linked to the period of this study, since the species is usually seen starting to September to November (Galliani et al., 2017). Breeding was not confirmed in the study area.

Genus Anax Leach, 1815

Anax imperator (Leach, 1815)

Regularly observed from June to September 2018 and 2019 in all the sunny and open habitats (not along the Brace stream), both sexes, also during mating and oviposition. Also recorded in Monte Chiapparo.

Anax parthenope (Selys, 1839)

Only few imagoes observed in August and September 2018 and 2019, exclusively near the pond of mountain S. Agata. Breeding highly probable but not confirmed. Also recorded in Monte Chiapparo.

Familia LIBELLULIDAE Rambur, 1842 


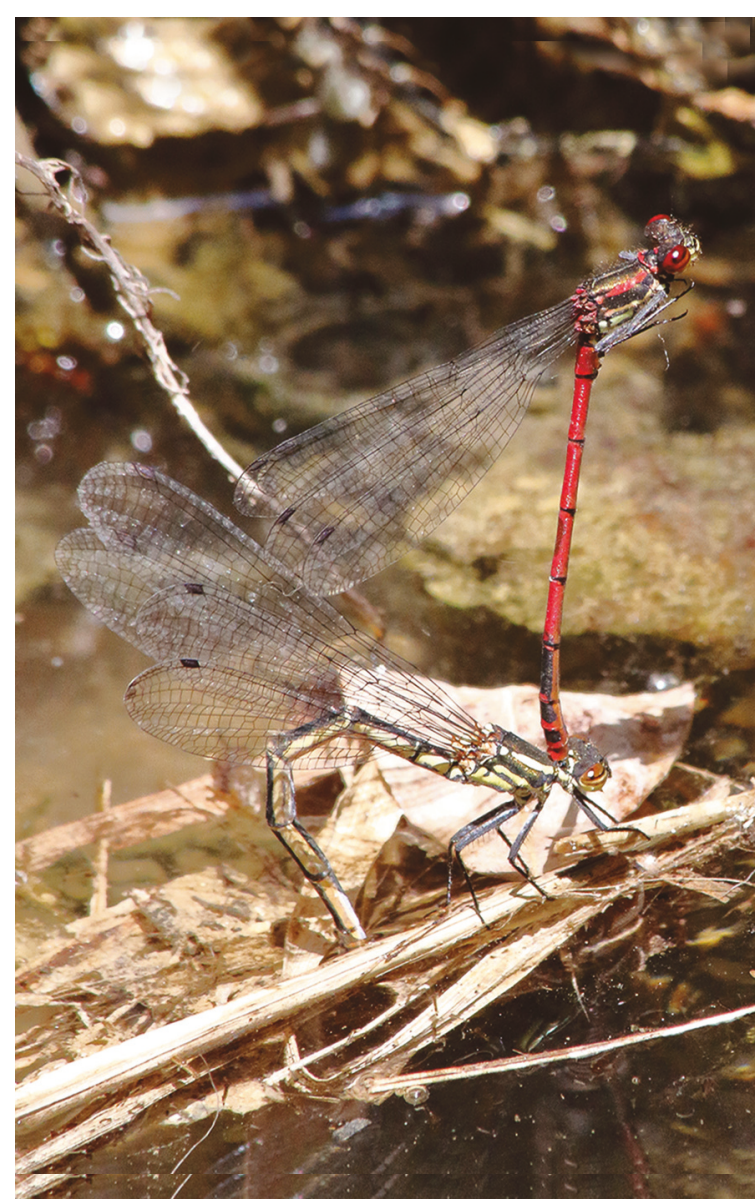

Figure 4. Pyrrhosoma nymphula oviposition photographed on 28.V.2018 (photo P. Galasso).

Genus Orthetrum Newman, 1833

Orthetrum brunneum (Fonscolombe, 1837)

The commonest Orthetrum in the study area: males regularly observed in all the sunny habitats from to May to September, both in 2018 and 2019. Also observed in tandem and mating.

\section{Orthetrum coerulescens (Fabricius, 1798)}

Only few males observed in August 2018 in the middle part of Brace stream, in small natural lakes. Breeding was not confirmed.

\section{Orthetrum trinacria (Selys, 1841)}

Few males and females regularly observed in August and September of both years but exclusively in the big pond/lake of S. Agata mountain. Breeding probable but not confirmed.

Genus Crocothemis Brauer, 1868

\section{Crocothemis erythraea (Brullé, 1832)}

Commonly observed in all kinds of habitats, from April to September, even without high numbers of imagoes, also in tandem, mating and oviposition. Also recorded in Monte Chiapparo.

Genus Sympetrum Newman, 1833

\section{Sympetrum fonscolombii (Selys, 1840)}

Observed from late March to September 2018 and 2019 in sunny and open habitats (not along the Brace stream), often far away from water, also in tandem and mating. Also recorded in Monte Chiapparo.

\section{Sympetrum meridionale (Selys, 1841)}

Only few imagoes (4-5 in total) observed in August and September 2018 and 2019 in sunny and open habitats (not along the Brace stream), also in tandem and mating.

\section{Sympetrum striolatum (Charpentier, 1840)}

The commonest Sympetrum in the study area; regularly observed from July to September of both years, exclusively in sunny habitats often far away from water, also in tandem and mating. Also recorded in Monte Chiapparo.

Genus Trithemis Brauer, 1868

Trithemis annulata (Palisot de Beauvais, 1807)

Few imagoes observed in August and September 2018 and 2019, exclusively near the pond of S. Agata mountain. Males and females also observed in tandem and a female during oviposition. Recorded also in Monte Chiapparo.

Genus Selysiothemis Ris, 1897

Selysiothemis nigra (Vander Linden, 1825) 


\begin{tabular}{|c|c|c|c|}
\hline ORDER & SUBORDER & FAMILY & SPECIES \\
\hline \multirow{24}{*}{ Odonata } & \multirow{23}{*}{ Zygoptera } & Calopterygidae & Calopteryx haemorrhoidalis (Vander Linden, 1825) \\
\hline & & Lestidae & Sympecma fusca (Vander Linden, 1820) \\
\hline & & & Chalcolestes viridis (Vander Linden, 1825) \\
\hline & & \multirow{5}{*}{ Coenagrionidae } & Ceriagrion tenellum (de Villers, 1789) \\
\hline & & & Coenagrion scitulum (Rambur, 1842) \\
\hline & & & Erythromma viridulum (Charpentier, 1840) \\
\hline & & & Ischnura genei (Rambur, 1842) \\
\hline & & & Pyrrhosoma nymphula (Sulzer, 1776) \\
\hline & & $\begin{array}{l}\text { Sub-total of families: } \\
\mathbf{3}\end{array}$ & Sub-total of species: 8 \\
\hline & & \multirow{4}{*}{ Aeshnidae } & Aeshna isoceles (Müller, 1767) \\
\hline & & & Aeshna mixta Latreille, 1805 \\
\hline & & & Anax imperator Leach, 1815 \\
\hline & & & Anax parthenope (Selys, 1839) \\
\hline & & \multirow{9}{*}{ Libellulidae } & Orthetrum brunneum (Fonscolombe, 1837) \\
\hline & & & Orthetrum coerulescens (Fabricius, 1798) \\
\hline & & & Orthetrum trinacria (Selys, 1841) \\
\hline & & & Crocothemis erythraea (Brullè, 1832) \\
\hline & & & Sympetrum fonscolombii (Selys, 1840) \\
\hline & & & Sympetrum meridionale (Selys, 1841) \\
\hline & & & Sympetrum striolatum (Charpentier, 1840) \\
\hline & & & Trithemis annulata (Palisot de Beauvois, 1807) \\
\hline & & & Selysiothemis nigra (Vander Linden, 1825) \\
\hline & & $\begin{array}{l}\text { Sub-total of families: } \\
2\end{array}$ & Sub-total of species: 13 \\
\hline & Total & Families: 5 & Number of species: 21 \\
\hline
\end{tabular}

Table 1. List of all the species recorded in the studied area of "Vallone di Piano della Corte", near Agira (Enna), Sicily. 
Only few males observed from June to August 2018 and 2019, exclusively around the pond of S.Agata mountain. Breeding was not confirmed in the study area.

\section{DISCUSSION AND CONCLUSIONS}

A total of 21 different species were found in Vallone di Piano della Corte of which 8 belong to the Zygoptera suborder and 13 to the Anisoptera suborder. The following families are so represented: 1 species of Calopterygidae (Odonata, Zygoptera), 2 species of Lestidae (Odonata, Zygoptera), 5 species of Coenagrionidae (Odonata, Zygoptera), 4 species of Aeshnidae (Odonata, Anisoptera), 9 species of Libellulidae (Odonata, Anisoptera). In addition to these species, Lestes barbarus (Fabricius, 1798) was found exclusively in the nearby area of "Monte Chiapparo" and observed and photographed also in copulation.

Particularly interesting is the record of Pyrrhosoma nymphula, species found regularly in Sicily only on Nebrodi Mountains since 2009 up to 2019, and, occasionally in some stations on Hyblaean Mountains, Sicani Mountains and Madonie Mountains (Corso, pers. obs.). From a point of view of conservation, all the species recorded are currently included by the Italian Dragonflies Red List into the LC (Least Concern) IUCN category, both for the Italian and global population (Riservato et al., 2014b).

Despite the fact that Vallone di Piano della Corte is not a wetland, the diversity and heterogeneity of its habitats, including small artificial niches as troughs and water reservoirs, allowed to find up to the $37 \%$ of the Sicilian species in such a small area. The richness of species in the site encourage activities of ecoturism such as Dragonflies-watching.

This survey shows, once again, the importance of smaller water habitats, that for their essential ecological function, can be much richer of dragonflies and biodiversity in general than what we could have expected, mainly when water sources around are not available.

Considering the current deficiency of published data about dragonflies distribution in Sicily, this survey and the check list hereafter add important information to our fragmented knowledge, mainly for the central Sicily.

\section{ACKNOWLEDGMENTS}

We want to thank Andrea Corso for his personal observations and critical arrangement of the text, Bruno Massa for his advice and conclusive remarks and Salvatore Surdo for sharing data and personal observations. We also want to thank Carlo Prato, Alessia Marzo, Grazia Savarino and Lidia Saglimmeni.

\section{REFERENCES}

Boudot J.-P., Kalkman V.J., Azpiliculeta Amorín M., Bogdanović T., Cordero Rivera A., Degabriele G., Dommanget J.-L., Garrigós B., Jović M., Kotarac M., Lopau W., Marinov M., Mihoković N., Riservato E., Samraoui B. \& Schneider W., 2009. Atlas of the Odonata of the Mediterranean and North Africa. $\mathrm{Li}$ bellula, Supplement 9: 1-256.

Boudot J.-P. \& Kalkman V.J. (Eds.), 2015. Atlas of the dragonflies and damselflies of Europe. KNNV Publishing, Zeist.

Corso A. \& Penna V., 2020. Orthetrum chrysostigma (Burmeister, 1839): new for the Italian fauna (Odonata Libellulidae). Biodiversity Journal, 11: 359-362. https://doi.org/10.31396/Biodiv.Jour.2020. 11.2.359.362

Costanzo E., Pavone P., Spampinato G., Tomaselli V., 2005. Analisi floristico-vegetazionale della Riserva Naturale Orientata "Vallone Piano della Corte" (Agira, Sicilia) finalizzata alla pianificazione ambientale. Quaderni di botanica Ambientale e Applicata, 16: $127-158$.

Galasso P., Curcuraci N. \& Marletta A., 2016. First record of Brachytron pratense (Muller, 1764) in Sicily (Odonata Aeshnidae). Biodiversity Journal, 7: 51-54.

Galliani C., Scherini R. \& Piglia A., 2017. Dragonflies and Damselflies of Europe. WBA Handbooks 7, Verona: $1-352$.

Riservato E., Festi A., Fabbri R., Grieco C., Hardersen S., La Porta G., Landi F., Siesa M.E. \& Utzeri C., 2014a. Odonata. Atlante delle libellule italiane - preliminare. Società Italiana per lo Studio e la Conservazione delle Libellule. Edizioni Belvedere, Latina, $224 \mathrm{pp}$.

Riservato E., Fabbri R., Festi A., Grieco C., Hardersen S., Landi F., Utzeri C., Rondinini C., Battistoni A. \& Teofili C., 2014b. Lista Rossa IUCN delle libellule italiane. Comitato italiano IUCN e Ministero del- 
1'Ambiente e della Tutela del Territorio e del Mare, Roma.

Surdo S., 2017. First record of Lindenia tetraphylla (Vander Linden, 1825) and rediscovery of Orthetrum nitidinerve (Selys, 1841) in Sicily (Insecta Odonata).
Fragmenta entomologica, 49: 1-5

Viganò M., Janni O. \& Corso A., 2017. Tramea basilaris on Linosa Island, Italy: A new species for Europe and the Western Palaearctic (Odonata: Libellulidae). Odonatologica, 46: 55-66. 